\title{
Transformational Learning in Higher Education Settings: A Case Study of "Teaching Teachers to Teach"
}

\author{
Sonya Hidalgo ${ }^{1, *}$, Mark Koebernik ${ }^{2} \&$ Kathlene Williams ${ }^{1}$ \\ ${ }^{1}$ College of Nursing and Health, McNeese State University, Box 91820, Lake Charles, LA, \\ 70609, United States of America \\ ${ }^{2}$ College of Education, Northwestern State University, 175 Sam Sibley Dr., Natchitoches, LA, \\ 71497, United States of America \\ *Corresponding author: College of Nursing and Health, McNeese State University, Box \\ 91820, Lake Charles, LA, 70609, United States of America. Tel: 1-337-562-4258. E-mail: \\ shidalgo1@mcneese.edu
}

Received: October 8, 2018 Accepted: November 2, 2018 Published: November 13, 2018

doi:10.5296/ije.v10i4.13750ＵRL: https://doi.org/10.5296/ije.v10i4.13750

\begin{abstract}
Transformational learning (TL) theory posits that adult students experience a disorienting dilemma and then engage in critical self-reflection (Mezirow, 1997). University faculty are often not pursuant toward improving andragogy skills, including utilizing TL. The purpose of this study is to determine if student achievement would increase if higher education faculty were trained to be better teachers in addition to being experts in their chosen field.
\end{abstract}

Keywords: adult education, transformational education, andragogy, higher-education 


\section{Background}

Learning and teaching go hand-in-hand, and effective teaching can certainly help the learning to occur. Several instructional theorists influence instructional design, in complimentary ways. Learning involves change causing one to transform from a previous state to a changed future state (Knowles, 1973). Transformative learning involves an evolution of a learner's perspective, where he or she will self-examine and reflect to influence their learning (Mezirow, 1978). Within the spectrum of learning, there are also different formats defined. Howard Gardner defined nine intelligences and examined how the educational system assumes everyone can learn material in the same way (Lunenburg \& Lunenburg, 2014). Adept educators use this knowledge to evolve their teaching style, as needed. To help students learn large concepts, scaffolding (to breakdown lessons into smaller parts) can be utilized to build up (or climb up a staircase) to the large sections (Bruner, 1983).

\subsection{Transformational Learning}

Not all learning that takes place is transformational, but all events of transformational learning qualify as a type of learning (Mezirow, 1991). Where one may have pictured all learning events as being comparative, Mezirow brings a new level to the stage.

One of the cornerstones of differentiating pedagogy from andragogy is breadth of experiences that the adult student brings to the event (Knowles, 1973). Mezirow's theory of Transformational Learning utilizes this difference to state that adult students have a "frame of reference" or a "meaning perspective" (Mezirow, 2000, p. 16). Adults have a context to learn the material within that children simply do not possess. As adults with previous experiences, they have multiple frames of reference to use when assimilating new material.

Mezirow also theorized about adult students using critical reflection to learn in transformative ways (Mezirow, 2000). By observing and participating in events, one can learn to gain perspective and reflect on the situation from a critical point of view. The theory continues in stating that as one becomes able to be critically reflective of others' statements, he or she learns better problem-solving skills and critical thinking (Mezirow, 1997). One negative viewpoint of this part of his theory has raised the question of assessment: how one knows when he or she is being critically versus non-critically reflective (Collard \& Law, 1989).

Lastly, TL utilizes self-assessment to determine if the adult student's previous choices were adequate, considers the actions of others, and plans future steps (Mezirow, 2000). A "disorienting dilemma" (Mezirow, 2000, p. 22) occurs, which causes one to ponder his or her own perspectives and self-assess their patterns of thought. So many adult learners are focused on grades and the final goal, that they can lose sight of the main point: developing a new perspective of the world around them.

\subsection{Critiques of Transformational Learning}

Critics of the Transformational Learning theory attempt to debunk it by titling it as conceptual or redundant (Taylor \& Cranton, 2012; Howie \& Bagnall, 2013); yet these perspectives do not actually change the interpretation of the core of theory at all. These anti-TL theorists still identify learning in a similar way: that the learner experiences a change. They seem to dislike 
the narrow field of what a disorienting dilemma is and what counts as a transformation. These counter-theories are very similar to Mezirow's theory of TL, with adjusted definitions of perspective and frames of reference. Even Mezirow's critics seem to agree that learning transforms the learner; they differ on terminology and acceptance of what counts as transformation.

Taylor and Cranton fluctuate from attempting to debunk TL as a learning theory to accepting it and stating that it should be expanded upon with additional areas of concern (Taylor \& Cranton, 2012). Planning expansions of the TL theory intrinsically values it as a theory; one cannot also in the same body of work state that it does not carry the weight of being a theory. As one cannot critique a boss without accepting of the person in that role, one cannot critique the core theory of TL without accepting it as a verified theory; hence the argument of it not weighing enough to be a theory is simple anemic. For example, Mezirow's TL theory has been termed as lacking the clarity and direction needed for proper utilization (Dirkx, 1998). A theory lacking clarity may have room for improvement, but that opinion does not discount it as a theory. This argument for TL to not be a theory of learning is weak at best.

\section{Problem in Higher Education}

There is a widening performance gap between the material taught by the faculty and the material retained by the students. This is due to the faculty not being as well versed in the knowledge of the latest research-based teaching methods, and their lack of knowledge of the learning styles of their students. The stakeholders are the students, faculty, administrators, and instructional designers of the learning session; these stakeholders expect to see an improvement in the learning outcomes of the students. When their grades improve, the dropout rates become lower and student graduation rates rise. There will also be an improvement in the evaluations of the teachers by the students. There would be an improvement in the pride felt by both the teachers and the students in the successes and achievements of the students

\subsection{Higher-Education Shortcomings}

Many second-career educators struggle with andragogic themes and methods. When working in private industry, one is assigned to attend trainings and in-services to learn about new instrumentation and methodologies, to then return and teach your colleagues. These adult learners were motivated to absorb the material, not only as a job requirement, but also because the knowledge was relevant and needed for the performance of duties. Currently in college classrooms, most adult students are lacking needed experience and the levels of participation and motivation vary greatly. Some students perform to the lowest possible level to obtain a passing grade, while others work hard to obtain the highest grade possible. Unfortunately, even the high achievers seem to be working toward a grade, rather than toward knowledge acquisition. This creates a large problem when the industry-specific educator cannot address learning shortcomings and varying styles. 


\subsection{Social Influences}

In the 'Social Participation' model (Smith, 2010), learners participate because of the setting and social groups present. Within a work place, the social presence can act as a positive force toward adult education. When one's coworkers openly discuss journal articles and scientific current events, the social pressures to take part in these types of activities aid to encourage that same behavior.

In the college and university setting, however, the social effect often acts as a barrier rather than an asset. Often, the social attitude of getting by with the minimum amount of work and other dispositional barriers act as a barrier for some of the struggling adult students (Merriam, Caffarella, \& Baumgartner, 2007). The students often express that they are tired of being in school and of having to work to bring up their low grades. To help motivate students for participation, one can follow Bruner's lead and build the material as a staircase, where beginning concepts must be mastered before moving up to more complex material (Bruner, 1983). During class, the use of open-ended questions to encourage verbal feedback and starting with small assignments for new material can aid in student participation. By breaking up the material into smaller chunks, it seems less intimidating toward the learners. For those most difficult and resistant learners of all, ending a section with a comprehensive review allows them to see how the concepts fit together in the end.

\section{Pilot Project}

A pilot project was held to determine if higher education faculty could utilize TL and other teaching strategies to improve student performance and outcomes. A professional development seminar was planned for an optional faculty retreat session at the participating university. An example instructional plan is located in Appendix 1 and Appendix 2.

\subsection{Intended Learners}

The learners/students are a heterogeneous group of university faculty that vary between adjunct instructors, non-tenure track instructors, tenure-track professors, and full-tenured professors. Their educational level is a minimum of a master's degree. There is a wide range of ages and ethnicities, of both genders. Their level of experience varies between novice instructors to faculty that have been at the university for thirty or more years. The instructors/designers are master's-degreed individuals currently working toward educational doctorates. Their curriculum is one that specializes in professional learning development sessions for educators at both the K-12 and higher education levels.

\subsection{Goals of Educators' Sessions}

The goal of this professional development session will be for the faculty members to be able to demonstrate teaching strategies that incorporate various learning styles. The incorporation of these new learning strategies into the teachers' lesson plans will increase the retention of the material by the students, which will improve their grades. An example planning document is demonstrated in Table 1. 
Table 1. Planning Document

\begin{tabular}{ll}
\hline & Activity \\
\hline Purpose & To heighten the teaching flexibility and perspectives of higher education \\
faculty. Research demonstrates that the majority of higher education classes are \\
taught in lecture-style settings (Preville, n.d.). Faculty perspectives should be \\
broadened with simulations to appreciate styles of active classroom teaching, \\
with adaptions for differing student learning styles. \\
Intended \\
The learners will exit with increased knowledge and understanding of how to \\
access their students' learning styles and adapt their teaching to accommodate \\
these styles. \\
Instructors and professors currently employed at an institution of higher \\
learning; future hires can be integrated into this cohort with annual trainings \\
scheduled. \\
Participants will engage in active learning sessions to learn about and practice \\
different teaching styles based on research-based strategies. Roles will be \\
assigned to participating faculty, to act as teacher or student. \\
Participants will be considered as proficient in this activity if they successfully \\
plan and execute a lesson addressing at least four different teaching/learning \\
styles. Each participant is also expected to act as student for other participants. \\
Each participant raising their hand and participating at least $50 \%$ of the time \\
measures success during the course. It is measured at the end of the course by \\
the successful completion of a lesson. There is no planned formal assessment \\
prior to the lesson. No pretest will be administered; it is already assumed that \\
learners begin this course with varying amounts of preexisting knowledge. \\
During the lesson, an assessment will be given to determine of planning and \\
execution of a lesson during role-play, meeting the criteria previously \\
explained. After the lesson, this information can be used in reports given to \\
administration for use in Annual Performance Reviews (APR). \\
Assessment
\end{tabular}

An example planning document to plan for sessions

\subsection{Purpose of Evaluations}

The purpose of the evaluations of the teaching methods is to determine the capabilities of the faculty to teach lessons using active classrooms and addressing various learning styles. The desired results are to be able to demonstrate positive outcomes on faculty knowledge and utilization of active teaching methods. Many of the faculty want to learn to teach more effectively and want these types of in-services. Administration, in efforts to bolster student recruitment and retainment, desire these evaluations to strengthen the core university teaching staff. All faculty and their supervisors are expected to participate in the evaluations, including possible future peer-observations. 


\subsection{Limitations}

The targeted learners consist of a heterogeneous group of university faculty; varying among non-tenure track instructor, tenure-track professor, and full-tenured professor. The educational level is a minimum of a master's degree. Age, ethnicity, and gender vary greatly, and are not allowed to have a bearing upon employment or assignment, but should cause an affect upon instructional design. Older adults tend to struggle with adapting to new methods, including technological advances, teaching style, etc. More resistance is expected proportionally to the older the faculty member (Terhart, 2013).

\section{Conclusion}

Getting higher education faculty on-board to new and innovative teaching methodologies can be difficult. Transformative learning opportunities could serve a role in changing the landscape of higher education settings. Novice and experienced faculty can benefit from teaching in-services and professional development, if they are willing to participate. Higher education faculty who can utilize TL, scaffolding, and other research-based strategies will benefit the students and the university.

\section{References}

Bruner, J. S. (1983). Education as social invention. Journal of Social Issues, 39(4), 129-141. https://doi.org/10.1111/j.1540-4560.1964.tb01712.x

Dirkx, J. (1998). Transformative learning theory in the practice of adult education: An overview. PAACE Journal of Lifelong Learning, 7, 1-14.

Howie, P., \& Bagnall, R. (2013). A beautiful metaphor: Transformative learning theory. International Journal of Lifelong Education, 32(6), 816-836. https://doi.org/10.1080/02601370.2013.817486

Knowles, M. (1973). The adult learner: A neglected species. [Adobe PDF]. Retrieved from https://files.eric.ed.gov/fulltext/ED084368.pdf

Lunenburg, F., \& Lunenburg, M. (2014). Applying multiple intelligences in the classroom: A fresh look at teaching writing. International Journal of Scholarly Academic Intellectual Diversity, 16(1), 1-14.

Merriam, S. B., Caffarella, R. S., \& Baumgartner, L. M. (2007). Learning in adulthood: A comprehensive guide (3rd ed.). San Francisco, CA: Jossey-Bass.

Mezirow, J. (1978). Perspective transformation. Adult Education Quarterly, 28(2), 100-110. https://doi.org/10.1177/074171367802800202

Mezirow, J. (1991). Transformative dimensions of adult learning. San Francisco, CA: Jossey-Bass.

Mezirow, J. (1997, Summer). Transformative learning: Theory to practice. New Directions for Adult and Continuing Education, 74, 5-12. https://doi.org/10.1002/ace.7401 


\section{Macrothink}

International Journal of Education

ISSN 1948-5476

2018, Vol. 10, No. 4

Mezirow, J. (2000). Learning to think like an adult: Core concepts of transformation theory. San Francisco, CA: Jossey-Bass.

Preville, P. (n.d.). The active learning handbook: Engagement techniques that work. Retrieved from Top Hat: https://tophat.com

Ross-Gordon, J. M., Rose, A. D., \& Kasworm, C. E. (2017). Foundations of adult and continuing education. San Francisco, CA: Jossey-Bass.

Smith, M. K. (2010). Participation in learning projects and programmes. The encyclopaedia of informal education.

Retrieved

from http://infed.org/mobi/participation-in-learning-projects-and-programmes/

Taylor, E., \& Cranton, P. (2012). The handbook of transformative learning theory, research, and practice. [Google Books version]. Retrieved from https://play.google.com/books/

Terhart, E. (2013, M). May 17. Teacher resistance against school reform: reflecting an inconvenient truth, 33. https://doi.org/10.1080/13632434.2013.793494 


\section{Appendix}

Appendix 1. Example Instructional Plan

\begin{tabular}{|c|c|c|c|}
\hline $\begin{array}{l}\text { Time } \\
(\mathrm{min})\end{array}$ & $\begin{array}{c}\text { Topic \# } \\
\text { Learning Objective(s) (LO) }\end{array}$ & Main Focus & $\begin{array}{c}\text { Instructional } \\
\text { Techniques } \\
\end{array}$ \\
\hline 15 & Welcome & $\begin{array}{l}\text { Key information about } \\
\text { the session/ course }\end{array}$ & Presentation/ dialogue \\
\hline 60 & $\begin{array}{l}\text { \#1: Learning new instructional strategies } \\
\text { LO: The faculty member will teach a lesson using a new } \\
\text { instructional strategy in a role play situation either in the } \\
\text { library or online; The "students" will actively respond to the } \\
\text { lesson by getting into small groups and taking part in group } \\
\text { discussions by raising their hands at least } 50 \% \text { of the time. }\end{array}$ & $\begin{array}{l}\text { To expose faculty } \\
\text { members to the latest } \\
\text { research-based teaching } \\
\text { strategies. }\end{array}$ & $\begin{array}{l}\text { PowerPoint } \\
\text { Presentation/discussion }\end{array}$ \\
\hline 60 & $\begin{array}{l}\text { \#2: Learning about Learning Styles } \\
\text { LO: The faculty member will integrate various learning } \\
\text { styles into each lesson within a course's timeframe utilizing } \\
\text { teaching methods for at least } 4 \text { different learning styles; The } \\
\text { "students" will actively respond to the lesson by getting into } \\
\text { small groups and taking part in group discussions by raising } \\
\text { their hands at least } 50 \% \text { of the time. }\end{array}$ & $\begin{array}{l}\text { To expose faculty } \\
\text { members to the latest } \\
\text { research-based learning } \\
\text { styles. }\end{array}$ & $\begin{array}{l}\text { PowerPoint } \\
\text { Presentation/discussion }\end{array}$ \\
\hline 60 & $\begin{array}{l}\text { \#3: Technology Review } \\
\text { LO: The "students" will actively respond to the lesson by } \\
\text { getting into small groups and taking part in group discussions } \\
\text { by raising their hands at least } 50 \% \text { of the time. }\end{array}$ & $\begin{array}{l}\text { To review the } \\
\text { technology that the } \\
\text { faculty will use in their } \\
\text { classrooms. }\end{array}$ & $\begin{array}{l}\text { PowerPoint } \\
\text { Presentation/discussion }\end{array}$ \\
\hline 60 & Break/lunch & & \\
\hline 60 & $\begin{array}{l}\text { \#4: Prepare for Role Play } \\
\text { LO: The "students" will actively respond to the lesson by } \\
\text { getting into small groups and taking part in group discussions } \\
\text { by raising their hands at least } 50 \% \text { of the time. }\end{array}$ & $\begin{array}{l}\text { For groups to prepare to } \\
\text { "teach" their lessons in } \\
\text { front of their } \\
\text { "classmates." }\end{array}$ & $\begin{array}{l}\text { Role play/PowerPoint } \\
\text { presentation/discussion }\end{array}$ \\
\hline 60 & $\begin{array}{l}\text { \#5: Role Play } \\
\text { LO: The "students" will actively respond to the lesson by } \\
\text { getting into small groups and taking part in group discussions } \\
\text { by raising their hands at least } 50 \% \text { of the time. }\end{array}$ & $\begin{array}{l}\text { Groups will "teach" } \\
\text { their lessons in front of } \\
\text { their "classmates." }\end{array}$ & $\begin{array}{l}\text { Role play/PowerPoint } \\
\text { presentation/discussion }\end{array}$ \\
\hline 30 & Conclusion: Evaluation of learning sessions & $\begin{array}{l}\text { Faculty members will } \\
\text { complete survey that } \\
\text { will inform instructional } \\
\text { designer of the faculty } \\
\text { members' opinions of } \\
\text { the professional } \\
\text { development session. }\end{array}$ & Discussion \\
\hline
\end{tabular}




\section{Appendix 2. Detailed Instructional Outline/Description}

Topic \# 1 ; Total time- 60 min:

Format/ Techniques: Introduction to role-play scenario, roles assigned, directions for roles given out

Learning Objective (s): The learner will: gain understanding of new instructional strategies.

\begin{tabular}{|c|c|c|}
\hline $\begin{array}{l}\text { Key points to } \\
\text { emphasize }\end{array}$ & $\begin{array}{l}\text { Time } \\
\text { (min) }\end{array}$ & Actions to take in instructional delivery \\
\hline \multirow{4}{*}{$\begin{array}{l}\text { - Importance of } \\
\text { students' learning and } \\
\text { retaining knowledge } \\
\text { - Being a stakeholder } \\
\text { in your university } \\
\text { - Research-based } \\
\text { instructional strategies } \\
\text { for active classrooms }\end{array}$} & 10 & $\begin{array}{l}\text { Lecture with visual aids to explain active classrooms, and how learners can } \\
\text { benefit from various exposures to information }\end{array}$ \\
\hline & 20 & $\begin{array}{l}\text { One participant role-plays as instructor to teach a pre-made lesson to the others- } \\
\text { utilizing one example active classroom style or method. The other participants } \\
\text { can take notes and raise hands for questions. }\end{array}$ \\
\hline & 20 & $\begin{array}{l}\text { Post-lesson, participants discuss the pros and cons of the style of teaching- was it } \\
\text { engaging? Did it explain the material in an interesting manner? }\end{array}$ \\
\hline & 10 & $\begin{array}{l}\text { Summary of the information gathered, with consolidation of feedback - a } \\
\text { T-chart may be useful for organization. }\end{array}$ \\
\hline
\end{tabular}

Topic \# 2 ; Total time- $\underline{60 \mathrm{~min}}$ :

Format/ Techniques: Utilizing a role-play scenario, learners will participate either as teacher or as students and gain experience with learning and teaching strategies based on different learning styles and fundamentals of active classrooms.

Learning Objective (s): The learner will: integrate various learning styles into lesson delivery during a simulation.

\begin{tabular}{|c|c|c|}
\hline $\begin{array}{l}\text { Key points to } \\
\text { emphasize }\end{array}$ & $\begin{array}{l}\text { Time } \\
\text { (min) }\end{array}$ & Actions to take in instructional delivery \\
\hline \multirow{6}{*}{$\begin{array}{l}\text { - Different } \\
\text { teaching and } \\
\text { learning styles } \\
\text { (Gardner) } \\
\text { - Methods to use } \\
\text { the different styles } \\
\text { of teaching to } \\
\text { engage more } \\
\text { students }\end{array}$} & 10 & $\begin{array}{l}\text { Lecture with visual aids to explain the roles being assigned, and reinforce how } \\
\text { learners can benefit from different teaching styles }\end{array}$ \\
\hline & 10 & $\begin{array}{l}\text { One participant role-plays as instructor to teach a pre-made lesson to the others- } \\
\text { utilizing one example teaching style. The other participants can take notes and } \\
\text { raise hands for questions. }\end{array}$ \\
\hline & 10 & $\begin{array}{l}\text { A different participant role-plays as instructor to teach a pre-made lesson to the } \\
\text { others- utilizing a different example teaching style. The other participants can take } \\
\text { notes and raise hands for questions. }\end{array}$ \\
\hline & 10 & $\begin{array}{l}\text { A different participant role-plays as instructor to teach a pre-made lesson to the } \\
\text { others- utilizing the previous two different teaching styles in one lesson. The other } \\
\text { participants can take notes and raise hands for questions. }\end{array}$ \\
\hline & 10 & $\begin{array}{l}\text { A different participant role-plays as instructor to teach a pre-made lesson to the } \\
\text { others- utilizing four different teaching styles in one lesson. The other participants } \\
\text { can take notes and raise hands for questions. }\end{array}$ \\
\hline & 10 & $\begin{array}{l}\text { Summary of the information gathered, with consolidation of feedback - a T-chart } \\
\text { may be useful for organization. }\end{array}$ \\
\hline
\end{tabular}




\section{Ml Macrothink}

Topic \# 3 ; Total time- $\underline{60 \text { min: }}$

Format/ Techniques: Informal lecture and group work to update learners on current available technology.

Learning Objective (s): The learner will: participate in small group discussions of the pros and cons of current technology available for educational uses.

\begin{tabular}{|l|c|l|}
\hline Key points to emphasize & $\begin{array}{c}\text { Time } \\
(\mathbf{m i n})\end{array}$ & \multicolumn{1}{|c|}{ Actions to take in instructional delivery } \\
\hline $\begin{array}{l}\text { - Current technologies } \\
\text { available for educational } \\
\text { purposes }\end{array}$ & 20 & $\begin{array}{l}\text { Lecture with visual aids to explore various current technologies available } \\
\text { for classroom utilization (examples include "Poll Anywhere" smart-phone } \\
\text { app, clickers, laptops, tablets, etc). }\end{array}$ \\
$\begin{array}{l}\text { Open discussion methods } \\
\text { to hear points of view from } \\
\text { all members of groups }\end{array}$ & 20 & $\begin{array}{l}\text { Group discussion about experiences with teaching using technology, } \\
\text { discussion of pros and cons }\end{array}$ \\
\cline { 2 - 3 } & 20 & $\begin{array}{l}\text { Open feedback session to gather and consolidate information gleaned from } \\
\text { the session. }\end{array}$ \\
\hline
\end{tabular}

Topic \# 4 ; Total time- 60 min:

Format/ Techniques: Informal lecture and group work to assign roles and directions for roles given out

Learning Objective (s): The learner will: practice roles of student and teacher, including following the directions given for the defined roles.

\begin{tabular}{|l|c|l|}
\hline Key points to emphasize & $\begin{array}{c}\text { Time } \\
(\mathbf{m i n})\end{array}$ & \multicolumn{1}{|c|}{ Actions to take in instructional delivery } \\
\hline $\begin{array}{l}\text { - Research-based } \\
\text { instructional strategies for } \\
\text { active classrooms }\end{array}$ & 20 & $\begin{array}{l}\text { Lecture with visual aids to explain active classrooms and different } \\
\text { learning/teaching styles and how learners can benefit from various exposures } \\
\text { to information. }\end{array}$ \\
$\begin{array}{l}\text { - Different teaching and } \\
\text { learning styles (Gardner) }\end{array}$ & 20 & $\begin{array}{l}\text { Participants plan their lesson as instructor to teach to the others- utilizing } \\
\text { four example teaching styles. }\end{array}$ \\
\cline { 2 - 3 } $\begin{array}{l}\text { - Methods to use the } \\
\text { different styles of teaching } \\
\text { to engage more students }\end{array}$ & 20 & $\begin{array}{l}\text { Open feedback session to gather and consolidate information gleaned and } \\
\text { give suggestions. }\end{array}$ \\
\cline { 2 - 3 }
\end{tabular}




\section{Macrothink}

Topic \# 5 ; Total time- $\underline{60 \text { min: }}$

Format/ Techniques: Learners will teach one lesson utilizing active classroom techniques and addressing at least four different learning styles.

Learning Objective (s): The learner will: plan and execute one lesson in an active classroom setting addressing a minimum of four different learning styles.

\begin{tabular}{|l|c|l|}
\hline Key points to emphasize & $\begin{array}{c}\text { Time } \\
\text { (min) }\end{array}$ & \multicolumn{1}{|c|}{ Actions to take in instructional delivery } \\
\hline $\begin{array}{l}\text { - Research-based } \\
\text { instructional strategies for } \\
\text { active classrooms }\end{array}$ & 10 & $\begin{array}{l}\text { Participants teach their lesson as instructor to the others (acting as students)- } \\
\text { utilizing four example teaching styles. }\end{array}$ \\
\cline { 2 - 3 } $\begin{array}{l}\text { - Different teaching and } \\
\text { learning styles (Gardner) }\end{array}$ & 10 & $\begin{array}{l}\text { Participants switch roles- a new participant acts as teacher - teaches lesson } \\
\text { using at least four teaching styles }\end{array}$ \\
\cline { 2 - 3 } $\begin{array}{l}\text { Methods to use the } \\
\text { different styles of teaching } \\
\text { to engage more students }\end{array}$ & 10 & $\begin{array}{l}\text { Participants switch roles- a new participant acts as teacher - teaches lesson } \\
\text { using at least four teaching styles }\end{array}$ \\
\cline { 2 - 3 } & 20 & $\begin{array}{l}\text { Participants switch roles- a new participant acts as teacher - teaches lesson } \\
\text { using at least four teaching styles }\end{array}$ \\
\cline { 2 - 3 } & $\begin{array}{l}\text { Open feedback session to gather and consolidate information gleaned and } \\
\text { give suggestions. }\end{array}$ \\
\hline
\end{tabular}

\section{Copyright Disclaimer}

Copyright for this article is retained by the author(s), with first publication rights granted to the journal.

This is an open-access article distributed under the terms and conditions of the Creative Commons Attribution license (http://creativecommons.org/licenses/by/3.0/). 